Годишњак Филозофског факултета у Новом Саду, Књига ХХХVII (2012)

Срђан Шљукић и Марица Шљукић Филозофски факултет Универзитета у Новом Саду

УДК 316.48 Spengler Oswald

ssljukic@yahoo.com

\title{
КУЛТУРЕ И СУКОБИ: ОСВАЛД ШПЕНГЛЕР
}

У овом раду аутори настоје да представе и анализирају погледе немачког мислиоца Освалда Шпенглера на друштвене сукобе. Први део текста посвећен је Шпенглеровом методу у којем је нагласак на потреби различитог приступа природи, са једне стране, и историји (друштву, култури) са друге. У другом делу приказују се елементи Шпенглеровог поимања сукоба кроз четири теме: борба (сукоб) и рат, однос западне културе и сукоба, унутрашњи сукоби и могућност светског мира. На крају рада наглашава се значај Шпенглерових идеја у овој области за социологију.

Кључне речи: култура, рат, социологија, сукоб, циклизам.

Када се у лето 1918, пред крај Првог светског рата, појавила прва књига Шпенглерове Пропасти Запада, одмах је изазвала велико интересовање. До 1922. продато је 53000 примерака (у три издања), па је друга књига штамшана у 50000 копија (Вујић, 2003a). Д. Стоктон пише да је Пропаст 3anaда брзо постала веома читана у целом западном свету и да је име Освалда Шпенглера, у року од две године, постало познато многима, како образованима, тако и необразованима. Током наредне две деценије, идеје из овог дела биле су присутне у свим дискусијама о историји и о будућности. Стоктон се пита због чега је интерес за Шпенглеров рад у великој мери нестао у деценијама које су следиле. Док се припремао да напише есеј о Шпенглеру, овај је аутор, како сам каже, претражио шест милиона библиотечких јединица да би нашао једну једину књигу о животу Освалда Шпенглера, а ни та није била баш претерано информативна (Stockton, 2003). Зашто је то тако? Зашто је знање о Шпенглеру

1 Рађено у оквиру пројекта “Промене у друштвеној структури и покретљивости као чиниоци европских интеграција републике Србије, са посебним освртом на АП Војводине“ (179053), који финансира Министарство за просвету и науку Владе Републике Србије. 
и његовом раду толико избледело и нестало из савременог мишљења? Иако на почетку свог есеја обећава да ће на ова питања одговорити, Стоктон то не чини.

А одговор уопште није тежак. Проблем је само у томе што је Стоктона, вероватно, омело исто оно што је Шпенглера потиснуло у заборав. Једноставно, деценије које су наступиле након Другог светског рата, све до данас, донеле су апсолутни (идеолошки) тријумф оног мишљења којем се Шпенглер супротстављао. И либерализам и марксизам, иако по многоме различити, делили су став о непрекидном историјском прогресу човечанства, док је немачки мислилац био цикличар који је тврдио да је „човечанство“ само празна реч. Победа либерализма у последње две деценије прошлог века није ствари изменила, већ их је само поједноставила. Покушајте само да упоредите ставове Ф. Фукујаме (Крај историје и последюи човек), за којег је либерализам „крај историје“, са Шпенглеровим ставовима. Идеолошки гледано, Шпенглер је постао потпуно „out“, чак непожељан, јер су његове идеје могле да „замуте воду“ апсолутне доминације Запада и његове идеологије (либерализма). Заиста, зар је неко могао да очекује бројне расправе о аутору који није величао демократију (тврдио је да је она политички систем у којем је народ само објекат и у којем је најважнији елемент новац), који је парламентаризам сматрао (краткотрајном) западњачком творевином, бесмисленом и немогућом у другим културама, који је одбацивао уобичајене (западне) погледе на историју и њен развој, који је предвиђао пропаст Западне цивилизације и успон „хришћанства Достојевског“ (Шпенглер, 2003a; 2003б)?

Ако данас Шпенглер и бива идеолошки одбачен, то није разлог да не погледамо његове радове изблиза у намери да видимо да ли се од њега нешто може научити. У овом раду усредсређујемо се на његове погледе на друштвене сукобе, са идејом да их препознамо, систематишемо и кратко, онолико колико нам то простор дозвољава, упоредимо са класичним социолошким теоријама у овој области.

\section{„КОПЕРНИКАНСКО ОТКРИЋЕ“ У ИСТРАЖИВАҢУ ИСТОРИЈЕ}

Оно што најистакнутије представнике цикличке теорије друштва (и културе) спаја (осим, наравно, основне идеје) јесте чињеница да се методи 
које примењују значајно разликују од онога што се традиционално (тј. позитивистички) сматра научним методом. Тако П. Сорокин (Sorokin, 2002; Шљукић, 2010) употребљава оно што назива „логичко-значењски метод“. Суштина овог метода је у проналажењу «централног начела» које прожима све компоненте, повезујући их у целину и стварајући «универзум из хаоса неповезаних фрагмената». Да ли неко начело логичке интеграције ваљано, знамо онда када је оно кадро да издржи логичку проверу, али и када је у складу са «релевантним чињеницама». Други познати цикличар, А. Тојнби (Тојнби, 2002; Kaurin, 2007), држи да се методи погодни за истраживање неживе материје не могу примењивати на проучавање историје, те да је за ваљано објашњење у овој сфери неоходан ,,језик митологије“. У настојању да објасни механизам настанка и развоја цивилизације, он користи јудеохришћанске митове, класичну књижевност и симболику.

Шпенглер одлази најдаље, тврдећи да је „наука“ о природи (сам Шпенглер ставља наводнике), ,касни и пролазни феномен, који припада јесени и зими тих великих животних токова (тј. култура - С.Ш, М.Ш) и да она живи само неколико векова (...) као и да се у току тих векова њене могућности најзад исцрпљују (...) Тиранија разума коју ми не осећамо зато што сами представљамо њен врхунац, јесте у свакој култури епоха на размеђу између човека у пуној снази и старца (...) Њен најјаснији израз је култ егзактних наука, дијалектике, доказа, искуства, узрочности (...) егзактна наука иде у сусрет самоуништењу“ (Шпенглер, 2003a: 512, 571-572). Суштина његовог метода је у ставу да мртви облици (природа) могу бити схваћени путем математичког закона, а живи путем аналогије, па зато предлаже (упоредну) морфологију светске историје која мора да разликује органско од механичког, облик од закона, слику и симбол од формуле и система: „људи мисле да се баве историјским истраживањем ако прате склоп узрока и последица (...) осим нужности узрока и последице - назвао бих то логиком простора - у животу још постоји и логика времена органска нужност судбине (Шпенглер, 2003a: 35). Човек није само део природе, него и део историје, која се од природе битно разликује, као живо од мртвог, као постајање од посталог. Историју није довољно разумски сазнавати, она се мора сагледавати, а сагледавање је доживљајни чин: „Прави историјски поглед (...) припада области значења за који нису више меродавне речи „тачно“ и „лажно“ 
него „плитко“ и „дубоко“ (...) Природу треба обрађивати научно, а о историји треба маштати“ (Шпенглер, 2003а: 151). Док је за истраживаче природе квантитет од кључног значаја, историји је он потпуно туђ; разум, систем и појам ,умртвљују“ својим сазнавањем, а сагледавање даје душу.

Западноевропска култура разликује се од других култура управо својим смислом за историјско, али по томе је она изузетак, а не правило. Уобичајена схема развоја историје стари - средюи - нови век нема смисла за незападне културе, из ње само проговара „таштина западноевропског човека“ који тиме ограничава обим и позорницу историје, стављајући себе у центар. Ту схему Шпенглер назива птоломејским системом историје и предлаже увођење система у којем Антика и Запад немају повлашћено место у односу на Индију, Вавилон, Кину, Египат, арапску и мексичку културу, називајући тај систем коперниканским открићем. Не постоји никакав праволинијски успон светске историје, већ је то само „пуста жеља“ западног човека. „Човечанство“ је празна реч, „зоолошки појам“, оно „нема сврху, нема идеју, нема план, као ни род лептира или орхидеја (...) Ако се допусти да та утвара ишчезне (...) видеће се како израста чудно обиље правих облика (Шпенглер, 2003a: 46-54). Културе су организми, а знамо да живот сваког организма јесте одређен особинама врсте којој дати организам припада: „Свака култура има сопствене могућности израза који се појављују, сазревају, вену и никада се више не враћају“ (Шпенглер, 2003a: 54). Различите културе говоре различитим језицима и имају различите истине; за истраживача све оне важе, или не важи ни једна. Светска историја јесте историја култура као „живих бића највишег ранга“ која „одрастају у узвишеној безсврховитоси као цвеће у пољу“; она је слика „вечног обликовања и преображавања, чудесног постајања и нестајања органских облика“, а не некаква бескрајна „пантљичара“ (Шпенглер, 2003а: 55).

Три године након објављивања Пропасти Запада Шпенглер је у есеју Песимизам?, одговарајући својим критичарима, још једном сумирао свој метод: „Активна особа живи у свету појава и са њима. Она не захтева логички доказ; шта више, она га често не може разумети. „Физиогномички ритам“ (тј. витална веза имеђу појединаца и њиховог света) даје јој дубљи увид од било ког метода заснованог на логичком доказу“ (Шпенглер према Stockton, 2003: 12-13). Премда наглашава да између природе и историје, посталог и постајања, нема 
тачне границе, он иде тако далеко да тврди да се за сазнање природе човек може васпитати, а да се за сазнање историје човек рађа; сазнавање природе и историје разликују се као рад и стварање (Шпенгер, 2003a). Користећи овај и овакав, прилично неуобичајен метод, Шпенглер нам даје слику култура као великих организама, слику која се може упознати и преко бројних интерпретација, али коју је најбоље (као што је то редовно случај) упознати на самом извору. Писци ових редова не једном су се уверили да интерпретације, поготово ако је тумач идеолошки несклон аутору, знају понекад и да нешто искриве или пак прећуте.

\section{„ЖИВОТ КАО БОРБА“ И КУЛТУРЕ}

Једна од особености Шпенглеровог писања јесте и недовољна систематичност, што сваком читаоцу, а поготово оном који намерава да прецизно презентује његове ставове о одређеном проблему, знатно отежава задатак. Шпенглеров схватање друштвених сукоба у овоме нипошто није изузетак, а то значи да су аутори морали најпре да идентификују велики број фрагмената који се тичу сукоба, да би затим те фрагменте некако систематисали. ${ }^{2}$ На тај начин дошли смо до уочавања четири теме које се директно тичу нашег главног проблема: питање борбе и рата уопште; однос Запада (као културе), борбе и рата; унутрашњи сукоби; пацифизам и светски мир.

Разматрање прве наведене теме започећемо одломком из последњег Шпенглеровог рада, његовог кратког (на једној страници), телеграфски послатог одговора америчком листу Космополитен (Cosmopolitan) на питање о могућности светског мира. Он најпре констатује да је „мир жеља, а рат чињеница“ и наставља: „Живот је борба која укључује биљке, животиње и људе. То је борба међу појединцима, друштвеним класама, народима, нацијама, и може узети облике економског, друштвеног, политичког и војног такмичења. То је борба за моћ како би нечија воља превладала.“ Кад циљ не бива постигнут другим средствима, посеже се за последњим средством - насиљем (Spengler, 1936). Изједначавајући борбу са ратом, Шпенглер инсистира на неизбежности сукоба као таквих, наводећи да без сукоба, борбе, нема ни постојања, нема

2 Слично је и са Тојнбијем (Тојнби, 2002; Шљукић и Шљукић, 2011). Сорокин, међутим, своје разумевање сукоба излаже на много систематичнији и прегледнији начин (Sorokin, 2002; Шљукић, 2010). 
живота: „Један народ јесте само у односу на друге народе. А природни, њихов расни однос испољава се у међусобним ратовима (...) Рат је исконска политика свега живога, у толикој мери да су борба и живот у суштини исто, па се и живот гаси када се угаси воља за борбом (...) У сваком рату, између свих животних сила, поставље се питање ко ће да управља целином (...) Борба око поседовања и вршења моћи - то је прво и последње у тој борби. Ни револуције нису по томе изузетак (...) Па чак и светски мир, кад год је био остварен, није био ништа друго до робовање човечанства под режимом малог броја снажних природа које су одлучиле да владају“ (Шпенлер, 2003б: 561-562). ${ }^{3}$

Највиши облик и најмоћнија димензија историје јесте политика. Светска историја је историја држава, а историја држава је историја ратова: „Рат је вечни образац више људске егзистенције и земље и постоје ради рата; оне су знак спремности за рат“ (Spengler, 1920: 45). Слично Зимелу (Simmel), свом савременику, он се супротставља здраворазумског поимању сукоба као искључиво рушилачке силе и тврди како је „рат творац свих великих ствари“: „Све што је значајно у животу народа настало је победом или поразом“ (Шпенглер, 2003б: 457-458). „Американци“ се, на пример, нису уселили из Европе, већ је та нација настала „душевним потресом 1775, а пре свега Сецесионистичким ратом 1861-1865. године“ (Шпенглер, 2003б: 201).

Борба и рат чврсто су повезани са културом (културама), за Шпенглерову теорију најважнијим појмом. Битке су, уз низ других појава, један од облика испољавања одређене културе (Шпенглер, 2003a); истовремено, свака култура има свој „период дивовских борби“ који чини прелаз из оног што се назива „наполеонизам“ у последњи период цивилизације, „цезаризам“. Тај развојни степен обухвата два века и има га свака култура. ${ }^{4}$ У Кини се он назива „временом ратујућих држава“ (480-230. године пре Христа); у антици то је период између 300. и 50. године пре Христа (Шпенглер, 2003б: 531-532).

Поново слично Зимелу и његовом тумачу Козеру (Kozer, 2007), Шпенглер не сматра да су негативна осећања извор сукоба, већ их пре види као

3 Овде би свакако требало истаћи да Шпенглерово поимање „расе“ нипошто не треба поистовећивати са доминантним схватањима о овим питањима. Расу он повезује са „космичким и душевним“, са „временом и судбином“, истовремено оспоравајући и готово исмевајући ,данас уобичајени појам расе из дарвинистичког времена“ (Шпенглер, 2003б: 137-202).

4 И то по дефиницији, јер свака култура, као организам, прелази исти пут. 
последицу ситуације супротстављених интереса. Тако он наводи да су у Русији „истински популарни“ ратови увек били ратови против Турске, зато што је Турска представљала препреку руском настојању да преко Босфора и Дарданела изађе на топла мора. Из истог разлога, руске антипатије је заслужио и Наполеон (премда у његовом случају постоје и други разлози, као што је познато - С.Ш, М.Ш), затим Хабзбуршка монархија и, коначно, Немачка (Spengler, 1922).

Културе (има их осам: египатска, вавилонска, индијска, кинеска, античка, магијска, мексичко-перуанска и западна) јесу јединствене и непоновљиве појаве са посебном душом, тј. особеним карактеристикама, непреносивим на друге културе. Шпенглер далеко највише простора посвећује античкој и западној култури; ову другу, инспирисан Гетеом, он назива фаустовском и као главну њену карактеристику види „беспримеран“ нагон за даљином. Типичан импулс западњачке (фаустовске) душе је управо борба, савлађивање отпора, и то представља нашу другу тему. Ова култура тражи активност, одлучност и борбу за самоодржање, за разлику од античке за коју је идеал одрицање од борбе (стоици и епикурејци). За западну културу важи етос испољавања воље и моћи држава, привреде и технике - идеал је ,активно биће које се бори и побеђује“, борба за опстанак (Шпенглер, 2003a: 427-428; 461). Чак и само питање морала, „шта треба да радимо“, „за чим треба да тежимо“ представља део искључиво западног схватања света. Етика запада јесте захтев за моћи, за даљином - у томе су слични једни другима Лутер и Ниче, папе и дарвинисти, социјалисти и језуити. Наредна одлика ове етике јесте захтев да она важи за све и за сва времена, а ко другачије мисли и захтева, тај је грешник и непријатељь и против њега се мора борити без милости. Ову основну одлику фаустовске душе није могуће изменити, јер и сам покушај измене ту исту одлику претпоставља: ко се бори против „напретка“, тај мисли да је управо његова делатност „напредак“; „неморал“ је заправо нови морал, са истим нетрпељивим захтевом. „Све што је фаустовско тежи да влада“ (Шпенглер, 2003a: 462). Западна је култура преиначила и хришћанство, тражећи да се њен морал прогласи општом истином и наметне целом човечанству, видећи у свом постојању и деловању послање. ${ }^{5}$ Ни социјализам ту није изузетак, јер је и он фаустовски, искључив идеал.

Горе наведено чини разлог због којег западна култура, као ниједна

5 За „моралну изабраност Запада“ упореди: Шљукић (2011). 
друга, тежи простирању - политичком, привредном, духовном. Све се границе морају савладати, цела планета претворити у јединствен систем. Отуд потиче западни империјализам, чији је део и социјализам, који се намеће силом и представља типичан израз цивилизације као последњег стадијума једне културе. Тежећи безграничном, фаустовска култура није свесна своје ограничености: „(...) будућност Запада није једно „горе и напред“ без обала, у правци наших тренутних идеала и са неограниченим временом на располагању, него (...) је та будућности једна појава историје строго ограничена по облику и трајању, неизбежно предодређена, која обухвата више столећа“ (Шпенглер, 2003а: 79). Одлике западне културе узроковале су и насилну смрт мексичко-перуанске културе. Мексичко-перуанска култура била је слична античкој по недостатку „воље за моћ у техници“, што је омогућило да буде уништена уз помоћ „неколико дотрајалих топова и неколико стотина застарелих пушака“ (Шпенглер, 2003б: 56-57).

Западно „доба ратујућих држава“ почиње са Наполеоном. Огромне армије увек су спремне на поход, флоте се стално обнављају; непрестано постоји надметање у опреми, спремности, бројевима, техници. Први век овог динамичког, фаустовског облика „ратујућих држава“ завршава се са Светским ратом. Шпенглер ни на овом месту не оклева да предвиђа наредна дешавања и каже да ће, пошто је принцип опште војне обавезе превазиђен, бити уведене мање, професионалне војске. „Доба ратујућих држава“ ће се наставити, у ратовима ће учествовати цео свет, сви континенти. „Велики светски градски центри моћи располагаће по својој вољи мањим државама, њиховом облашћу, њиховом привредом и људима - које ће постати провинција, објекат, средство за циљ“ (Шпенглер, 2003б: 548-549).

На занимљив и (као и обично) неуобичајен начин Шпенглер пише о штампи и слободи штампе у западној култури, повезујући их са новцем и ратним сукобима. „Европско-америчка политика“ искористила је штампу да све појединце на Земљи, а да тога они тога нису свесни, примора да мисле и раде на начин на који то жели, негде далеко, нека владајућа личност. Штампа и „електрична обавештајна служба“ цео свет, без престанка, „бомбардују“ речима, паролама, гледиштима, осећањима. Новац тако престаје да бива само средство размене; он постаје сила за „обрађивање масе“. „Барут и штампа иду заједно 
(...) као два велика средства фаустовске тактике на даљину“, каже Шпенглер, а први пример употребе штампе као оружја јесте рат који се из Лондона водио против Наполеона лецима, новинским чланцима и фалсикованим мемоарима; рат путем штампе тако је постао продужење и проширење рата уобичајеним средствима. За масу је истина оно што може да прочита и што чује и зато је истина од тада производ штампе: ко има новца, за три недеље новинске пропаганде цео свет може да убеди у „истину“. Аргументи који се безброј пута понављају необориви су докле год има новца; ако се појави већи новац који подржава супротне аргументе, „истина“ се мења и сви се „ослобађају заблуде“. Штампа је организована као војска у којој су новинари официри, а читаоци војници; ако се циљеви и планови промене, официри слушају, док војници немају о томе појма. „Некада се људи нису усуђивали да слободно мисле; сада то смеју, али не могу. Они још само могу да мисле оно што треба да мисле и баш то осећају као своју слободу (...) свако слободно може да каже шта хоће; али штампа процењује хоће ли то да чује или не (...) може то пре свега страшном цензуром ћутања“. Шпенглер овакву улогу штампе види као „нужни резултат европско-америчком либерализма“ и ,крај демократије“ (Шпенглер, 2003б: 588-593). У целини гледано, његово схватање односа западне културе и борбе заправо представља уочавање, социолошки речено, једног културног обрасца.

Унутрашње сукобе (трећа тема) Шпенглер види као сукобе међу сталежима, сукобе који карактеришу сваку културу. Сама појава сталежа јесте знак буђења високе културе. Племство и свештенство стоје насупрот ономе што није сталеж већ само чињеница без дубљег значаја, тј. према сељаштву. Ту нема и не може бити помирења: „Из села избија мржња, са замкова се узвраћа презиром“. Са појавом града јавља се и трећи сталеж, грађанство, које такође презире село, али и старе сталеже. Рано доба културе карактеришу „нагонски сељачки ратови“, а касно „духовно засновани грађански ратови“ (Шпенглер, 2003б: 420-421). Важни су и сукоби „духовне и световне моћи“, у ствари племства и свештенства: у Сасанидском краљевству, у Византији, у Египту, у фаустовској култури. Јачање улоге града и појава грађанства ,предузима ново груписање сталежа“; рационализам најпре бива теорија, а затим, постепено, и пракса, све до „крваве праксе револуција“. Касно доба сваке културе значи и крај историје сталежа; цивилизација са собом доноси четврти сталеж, масу, 
несвесну свог порекла, безоблични ентитет који не признаје прошлост и нема будућност (Шпенглер, 2003б: 446-454). Саме револуције, као најоштрији облик унутрашњих сукоба, само су још један пример борбе око поседовања и вршења моћи - „сувереност народа“ значи само малу промену начина владања, а никакву промену за оне којима се влада (Шпенглер, 2003б: 562).

С обзиром на ставове о сталности борбе (види горе), не чуди што на питање о могућности светског мира (четврта тема) Шпенглер одговара да је „мир жеља, а рат чињеница; а историја никад није марила за људске жеље и идеале“. Пацифизам неког народа знак је његове сенилности и преласка моћи у руке оних који нису пацифисти (Spengler, 1936). Он је у тесној вези са космополитизмом, друштвено утемељеним у једној мањини која се рађа у светским градовима. Чине је „безвременски, безисторијски, литерарни људи, који мрзе и судбину и историју и више се не осећају припадницима нације. „Космополитизам је јак у разлозима, а врло слаб у одбрани својих разлога“ и њега је било и у Кини, Индији, хеленизму. Ови „рођени светски грађани и сањалице о светском миру и о измирењу народа“ имају велики значај у историји духа, али не и у „правој историји“. Судбина једне нације зависи од тога да ли она успева да космополитизам учини неефикасним, јер успех ових теорија не доноси сањани мир, већ корист другима. „Сам светски мир је увек једнострана одлука (...) светски мир, кад год је био остварен, није био ништа друго до робовање човечанства под режимом малог броја снажних природа које су одлучиле да владају“ (Шпенглер, 2003б: 226-229, 562).

Супротно ономе што се би се можда могло помислити, ни Шпенглеров метод, ни његова представа о културама, па ни његово поимање друштвених сукоба нису настали у некаквом идејном „вакууму“. Он сам истиче да је основе свог метода преузео од Гетеа и да доста дугује и Ничеу; у овом контексту он спомиње и Платона (Шпенглер, 2003a: 24-25, 92-93). Један број оних који су настојали да презентују и процене његове идеје, уз истицање оригиналности, уочио је читав низ утицаја који се у Шпенглеровој мисли могу препознати. Међу те утицаје спадају идеје Хегела, Данилевског, Достојевског, Бергсона, Винделбанда, Дилтаја, као и традиционалног немачког поимања културе (Вујић, 2003б; Kaurin, 2007; Berdyaev, 1922; Whistler; Stockton, 2003; Gottfried). 
Шпенглер, управо као и творци класичних социолошких теорија друштвених сукоба - у које рачунамо Маркса (Marx), Зимела, Козера и Дарендорфа (Dahrendorf) - даје сукобима веома значајно место и сматра их неизбежним. Заједничко са њима му је и то да је утемељен у немачкој идејној традицији. Иако Шпенглера не можемо сматрати социологом у традиционалном смислу, вредност његових идеја за социологију видимо у настојању да се продре с ону страну појавног и одбијању да се прихвати доминантна идеологија као „неоспорна истина“. Шпенглерови увиди у суштину друштвених сукоба могу бити оспоравани, али и брањени, при чему се мора правити јасна разлика између аргумената научне и идеолошке природе.

\section{ЛИТЕРАТУРА}

Berdyaev, N.A. (1922). The Pre-Death Thoughts of Faust. www.berdyaev. com/beridaev/berd_lib/1922_059.html.

Вујић, Владимир (2003а). Освалд Шпенглер и његово дело. Предговор за књигу: Шпенглер, О. Пропаст Запада, књига прва.

Вујић, В. (2003б). Шпенглерова морфолошка перспектива људске историје. Поговор за књигу: Шпенглер, О. Пропаст Запада, књига друга.

Gottfried, P. Oswald Spengler and the Inspiration of the Classical Age. www. mmisi.org/ma/26_01/gottfried.pdf.

Kaurin, D. (2007). Ciklične teorije društvenih promena - Špengler i Tojnbi. Sociologija, vol. 49, no. 4.

Kozer, L. (2007). Funkcije društvenog sukoba. Novi Sad: Mediterran Publishing.

Sorokin, P. (2002). Društvena i kulturna dinamika, Beograd i Podgorica: Službeni list i CID.

Spengler, O. (1920). Prussianism and Socialism. http://home.alphalink.com. $\mathrm{au} / \sim$ radnat/spengler/prussianism.html.

Spengler, O. (1922). The Two Faces of Russia And Germany's Eastern Problems. http://aphalink.com.au/radnat/spengler/twofaces.htm.

Spengler, O. (1936). Is World Peace Possible? Cosmopolitan January 1936. 
http://home.alphalink.com.au/radnat/spengler/worldpeace.htm.

Stockton, D. L. (2003). Oswald Spengler's Uneven Legacy. http:/home. alphalink.com.au/radnat/spengler/biographical.html.

Тојнби, А. (2002). Проучавағе историје. Београд и Подгорица: ЈП „Службени лист СРЈ“ и ЦИД.

Шљукић, С. (2010). „Сукоб из угла друштвене и културне динамике“. Зборник Сусрет култура. Нови Сад: Филозофски факултет.

Шљукић, С. (2011). Мит као судбина. Сремски Карловци: Каирос.

Шљукић, С. Шљукић М. (2011). Друштвени сукоб као пратилац цивилизација. Годишњак Филозофског факултета у Новом Саду, XXXVI-2.

Шпенглер, Освалд (2003a). Пропаст Запада, књига прва. Београд: Утопија.

Шпенглер, Освалд (2003б). Пропаст Запада, књига друга. Београд: Утопија.

Whistler, D. "The Dying Faust”: Berdiaev on Spengler. www.live.ac.uk/ dying\%Faust.pdf.

Srđan Šljukić, Marica Šljukić

\section{CULTURES AND CONFLICT: OSWALD SPENGLER}

\section{Summary}

In this paper the authors try to present and analyze the views of a German thinker, Oswald Spengler on social conflicts. The first part of the text deals with Spengler's method, which points out the need of different approach to nature on the one side, and history (society, culture) on the other. The second part presents the elements of Spengler's view on conflict, using four topics: struggle (conflict) and war, the Western culture and conflict, inner conflicts and possibilities of world peace. In the end of the paper the importance of Spengler's ideas for sociology is stressed.

Key words: conflict, culture, cyclic theory, sociology, war. 